\title{
Krónikus obstruktív tüdőbetegségben a bal kamra diasztolés funkciózavara gyakori és rossz prognózissal társul
}

\author{
Hajdu Máté, Krämer Konrád1, Vértes Vivien1, Nógrádi Ágnes', Varga Noémi², \\ Illés Miklós Balázs ${ }^{3}$, Sárosi Veronika ${ }^{4}$, Faludi Réka' \\ ${ }^{1}$ Pécsi Tudományegyetem, Klinikai Központ, Szívgyógyászati Klinika, Pécs \\ ${ }^{2}$ Medicover Klinika, Pécs \\ ${ }^{3}$ Landeskrankenhaus - Universitätsklinikum Graz, Universitätsklinik für Innere Medizin, Klinische Abteilung für \\ Pulmonologie, Graz, Ausztria \\ ${ }^{4}$ Pécsi Tudományegyetem, Klinikai Központ, I.sz. Belgyógyászati Klinika, Pulmonológia Tanszék, Pécs
}

Levelezési cím:

Dr. Faludi Réka, 7624 Pécs, Ifjúság u. 13., Fax: +36 72536 388, e-mail: faludi.reka@pte.hu

Bevezetés: A krónikus obstruktív tüdőbetegség (COPD) és a szívelégtelenség gyakrabban társul egymáshoz, mint az prevalenciájuk alapján indokolt lenne. Munkánk célja volt megvizsgálni, hogy a bal kamrai diasztolés funkciózavar gyakori-e COPD-s populációban és befolyásolja-e a betegek prognózisát.

Betegek és módszerek: Retrospektív kutatásunkba 66 beteg $(60,5 \pm 8,9$ év) került bevonásra, akiknél 2013 decembere és 2014 májusa között echokardiográfiás vizsgálat történt. A bal kamrai ejekciós frakció és a bal pitvari volumen mérése 2D Simpson-módszerrel történt. A mitrális beáramlási görbe paraméterei $(E, A)$ mellett szöveti Doppler segítségével szisztolés (S), valamint kora- (e') és késő- (a') diasztolés miokardiális sebességeket mértünk a mitrális anuluson. Kiszámítottuk az E/A és az E/e' arányt. Átlagosan 4,5 év követési idő után vizsgáltuk meg a betegek túlélését. Néhány esetben a halál oka nem volt egyértelműen tisztázható, így az összhalálozást vizsgáltuk.

Eredmények: 29 (43,9\%) fönél károsodott relaxációra utaló mintázat, míg 18 (27,3\%) betegnél emelkedett töltőnyomásra utaló eredmények voltak igazolhatók. Utóbbiak közül 17 esetben (25,8\%) pszeudonormális, míg 1 betegben $(1,5 \%)$ restriktív típusú mitrális beáramlási görbét találtunk. Az átlagosan 4,5 $\pm 0,6$ év követési idő alatt 5 (7,6\%) haláleset történt. Többváltozós Cox-regressziós analízis alapján az E/e' bizonyult az összhalálozás egyetlen független prediktorának (HR $(95 \% \mathrm{Cl})=1,372(1,104-1,706) ; p=0,004)$. ROC-görbe segítségével megállapítottuk, hogy 9,7 az az E/e' érték, ami a lehető legmagasabb szenzitivitással (80\%) és specificitással (77\%) képes megkülönböztetni a túlélő és elhunyt COPD-s populációt (AUC=0,727).

Következtetés: COPD-ben gyakori a bal kamrai diasztolés funkciózavar, különösen a károsodott relaxációra jellemző mintázat. A vizsgált paraméterek közül az E/e’ arány bizonyult a bármely okból bekövetkezett halálozás független prediktorának ebben a kórképben.

Kulcsszavak: COPD, szívelégtelenség, túlélés, echokardiográfia, bal kamrai diasztolés funkciózavar

A kézirat 2020. 07. 05-én érkezett a szerkesztőségbe, 2020. 10. 05-én került elfogadásra. 
Left ventricular diastolic dysfunction is common in patients with chronic obstructive pulmonary disease and is associated with worse prognosis

Background: Chronic obstructive pulmonary disease (COPD) and heart failure seem to coexist more frequently than expected based on their prevalence. Thus we aimed to estimate the prevalence and to investigate the prognostic value of the diastolic dysfunction in COPD patients.

Patients and methods: 66 patients (60.5 \pm 8.9 years) were enrolled into our retrospective study. They underwent echocardiography between December 2013 and May 2014. Left ventricular ejection fraction and left atrial volume were measured by 2D Simpson's method. In addition to the spectral Doppler parameters of the transmitral flow (E, A), myocardial systolic (S), and early- (e') and late- (a') diastolic velocities were measured on the mitral annulus by tissue Doppler technique. E/A and E/e' ratios were calculated. Survival of patients was assessed after 4.5 years. Since the exact cause of death was often unknown, all-cause mortality was chosen as outcome.

Results: Impaired relaxation pattern was found in 29 (43.9\%) patients. Doppler data suggested elevated filling pressure in $18(27.3 \%)$ patients, including $17(25.8 \%)$ and $1(1.5 \%)$ cases with pseudonormal and restrictive mitral inflow pattern, respectively. During the follow-up period of $4.5 \pm 0.6$ years, $5(7.6 \%)$ patients died. By multivariate Cox regression analysis, E/e' ratio was the only independent predictor of mortality $(\mathrm{HR}(95 \% \mathrm{Cl})=1.372(1.104-1.706) ; \mathrm{p}=0.004)$. Using $\mathrm{ROC}$ analysis, E/e' ratio $\geq 9.7$ was the strongest predictor of the mortality (sensitivity $=80 \%$, specificity $=77 \%, A U C=0.727$ ).

Conclusion: Left ventricular diastolic dysfunction is common in COPD, especially the impaired relaxation pattern. Among the investigated parameters, E/e' ratio was proved to be the only independent predictor of all-cause mortality.

Keywords: COPD, heart failure, survival, echocardiography, left ventricular diastolic dysfunction

\section{Bevezetés}

A krónikus obstruktív tüdőbetegség (COPD) a légutak falát és a tüdő intersticiális állományát érintő krónikus gyulladásos betegség, aminek kialakulásában a fő szerepet a dohányzás és a légszennyezés játssza. A betegség progresszióját az exacerbációk gyakorisága és a kísérőbetegségek nagyban befolyásolják (1).

A COPD-hez gyakran társul szívelégtelenség. Számos adat utal arra, hogy a két kórkép együttes előfordulása gyakoribb, mint ahogy prevalenciájuk alapján ez várható lenne (2-4). A két betegség negatívan befolyásolja egymás lefolyását: a szívelégtelenség társulása megduplázta a COPD-s betegek mortalitását a 4,2 éves követés során (3).

Közismert, hogy a dohányzás a COPD és a kardiovaszkuláris betegségek közös rizikófaktora. Ám számos más etiológiai tényező is leírásra került, amik magyarázhatják a két betegség közötti átfedést. Ilyenek a szisztémás gyulladás (2), a vaszkuláris diszfunkció (5), vagy a tüdő hiperinflációja (6).

A jól ismert „cor pulmonale” kifejezés a jobb szívfél funkciózavarát takarja. Ugyanakkor COPD-ben jelen van a bal szívfél müködésének zavara is. A vizsgálati módszerek, illetve a vizsgált populáció függvényében a szívelégtelenség prevalenciája COPD-s betegekben széles skálán változik (7). Az irodalmi adatok alapján ép koszorúér-rendszerü COPD-s betegekben a szisztolés balszívfél-elégtelenség (HFrEF) relatíve ritkán fordul elö, ám a diasztolés funkciózavar, illetve a megtartott ejekciós frakcióval járó szívelégtelenség (HFpEF) gyakoribb $(7,8)$.
A bal kamrai diasztolés funkciózavar gyakoriságának tekintetében ugyanakkor igen ellentmondásosak az adatok, mivel a különböző munkacsoportok eltérő módszereket alkalmaztak a bal kamrai diasztolés funkció megítélésére. Ezen kívül meglehetősen kevés adattal rendelkezünk a vizsgált echokardiográfiás paraméterek prognosztikai szerepéről COPD-s betegekben.

Így munkánk célja annak vizsgálata volt, hogy a bal kamrai diasztolés funkciózavar gyakori-e megtartott vagy mérsékelten csökkent ejekciós frakcióval bíró COPD-s populációban, illetve a bal kamrai diasztolés funkció jellemzésére használt echokardiográfiás paraméterek bírnak-e prognosztikus erővel ebben a kórképben.

\section{Betegek, módszerek}

\section{Vizsgált populáció}

Retrospektív kutatásunkba 66 beteg került bevonásra, akiknél 2013 decembere és 2014 májusa között echokardiográfiás vizsgálat, valamint $\mathrm{N}$-terminális B-típusú nátriuretikus peptidszint- (NT-proBNP) meghatározás történt (9).

A COPD diagnózisának felállítása és a betegek pulmonológiai kezelése az aktuális GOLD stratégiai dokumentum alapján történt (1). Azokban az esetekben, amikor határeset FEV1/FVC arány (az alsó normálérték felett, de 0,70 alatt) igazolódott, a COPD diagnózisának felállítása a klinikai tüneteken (fulladás, krónikus köhögés és/vagy köpetürítés) és a betegség rizikófaktorainak felmérésén alapult. Minden beteg a vizsgálatba 
való bevonása elött egy hónapon belül légzésfunkciós vizsgálaton vett részt.

A vizsgálatból kizártuk azokat a betegeket, akiknél közepes-súlyos bal kamrai szisztolés diszfunkció (ejekciós frakció $<45 \%$ ), pitvarfibrilláció, terhelhetőséget befolyásoló neuromuszkuláris rendellenesség, vagy a bal szívfél szignifikáns billentyüelégtelensége állt fenn, valamint az aorta vagy mitrális mübillentyü-hordozókat. A betegeknek exacerbációmentesnek kellett lenniük a vizsgálatot megelőző két hónapban.

Szignifikáns iszkémiás szívbetegséget állapítottunk meg invazív mérésekkel igazolt $50 \%$ feletti koronáriaszükület esetén, illetve ha korábban szívinfarktust szenvedett el a beteg. Kacsdiuretikum rendszeres szedése és/vagy bármely szívelégtelenségre jellemző tünet fennálása esetén szívelégtelennek tekintettük a betegeket.

A betegek túlélését 2019 januárjában vizsgáltuk meg. Követési időnek az echokardiográfiás vizsgálat és az utolsó klinikai megjelenés vagy a halálozás időpontja közötti intervallumot tekintettük. Az elhunytakról öszszegyüjtöttük a rendelkezésre álló orvosi dokumentációkat, valamint telefonon megkerestük a hozzátartozókat. Mivel a halál oka az esetek egy részében nem volt korrekten tisztázható, az összhalálozást választottuk a vizsgálat végpontjának.

Kutatásunk megfelelt a Helsinki Nyilatkozatban foglaltaknak, az intézményi etikai bizottság engedélyezte. Minden résztvevő beleegyező nyilatkozatot írt alá a képalkotó vizsgálatok megkezdése előtt.

\section{Echokardiográfia}

Az echokardiográfiás vizsgálatok Philips CX50 ultrahangkészülék (Philips Healthcare, Best, Hollandia) segítségével történtek.

A bal kamrai ejekciós frakciót biplane Simpson-módszerrel határoztuk meg. A Devereux-formula segítségével számoltuk ki a bal kamrai izomtömeget, majd testfelszínre korrigáltuk (LVM-index). A maximális bal pitvari térfogatot csúcsi négy-, illetve kétüregi nézetből Simpson-módszerrel határoztuk meg a mitrális billentyű nyílását megelőző pillanatban, majd testfelszínre normalizáltuk ( $\mathrm{V}_{\max }$-index) (10).

A jobb kamrai szisztolés nyomást a módosított Bernoulli-képlet alapján számoltuk ki a tricuspidalis regurgitáció sebességéből. A jobb pitvari nyomást a vena cava inferior tágassága és összenyomhatósága alapján becsültük (5-10-15 Hgmm) (11). Pulzatilis Doppler-technika segítségével határoztuk meg a mitrális beáramlási görbe jellemzőit, majd E/A arányt számoltunk. Szöveti Dopplerrel határoztuk meg a mitrális anulus szeptális és laterális régiójában az $S$, e' és a' hullám maximális sebességét. A szeptális és laterális értékeket átlagoltuk, majd E/e' arányt számoltunk (10). A Doppler-paraméterek esetében három mérés eredményét átlagoltuk.
A bal kamra diasztolés funkcióját az aktuális ajánlás alapján újraértékeltük:

- normál relaxáció: laterális e' $\geq 10 \mathrm{~cm} / \mathrm{s}$, szeptális $e^{\prime} \geq 7 \mathrm{~cm} / \mathrm{s}, \mathrm{E} / \mathrm{A} \geq 0,8, \mathrm{E} / \mathrm{e}^{\prime}<10$;

- károsodott relaxáció: laterális e'<10 cm/s, szeptális $e^{\prime}<7 \mathrm{~cm} / \mathrm{s}, E / A<0,8, E / e^{\prime}<10$;

- pszeudonormális mintázat: laterális e'<10 cm/s, szeptális e'<7 cm/s, E/A 0,8-2, E/e' 10-14;

- restriktív mintázat: laterális $e^{\prime}<10 \mathrm{~cm} / \mathrm{s}$, szeptális $\mathrm{e}^{\prime}<7 \mathrm{~cm} / \mathrm{s}, \mathrm{E} / \mathrm{A}>2, \mathrm{E} / \mathrm{e}^{\prime}>14$ (12).

\section{N-terminális B-típusú nátriuretikus} peptidszint- (NT-proBNP) mérés

Az NT-proBNP-szint mérése Roche Cobas H 232 POC készülékkel történt, heparinizált vénás vér felhasználásával, az echokardiográfiás vizsgálat napján.

\section{Statisztikai módszerek}

Kategorikus változók esetén a gyakoriságot százalék formájában tüntettük fel, a folytonos változók esetén eredményeinket átlag \pm szórás formájában adtuk meg. A folytonos változók esetén a csoportok összehasonlításához kétmintás t-próbát, illetve az NT-proBNP-értékek esetében Mann-Whitney-tesztet használtunk, míg a kategorikus változóknál khi-négyzet próbát alkalmaztunk. A vizsgált paraméterek túlélésre gyakorolt hatását egyszeres Cox-regresszióval vizsgáltuk. Az NT-proBNP nem mutatott normál eloszlást, ezért természetes alapú logaritmussá alakítottuk az értékeket (InNT-proBNP). Azokat a paramétereket, amelyek ebben a vizsgálatban $p<0,1$ szignifikanciát mutattak, többszörös Cox-regressziós egyenletbe rendeztük (backward stepwise), meghatározandó a túlélés független prediktorait. A többszörös Cox-regressziós vizsgálatban szignifikánsnak bizonyuló paraméter esetében ROC-görbét készítettünk, majd meghatároztuk a lehető legmagasabb szenzitivitással és specificitással bíró cut-off értéket. Ezen érték segítségével két csoportra osztottuk a vizsgált populációt, Kaplan-Meier-görbét készítettünk, majd Mantel-Cox-logrank tesztet alkalmazva vizsgáltuk a két csoport túlélése közötti különbséget. Statisztikailag szignifikánsnak a $p<0,05$ értékeket fogadtuk el. Adataink feldolgozását IBM SPSS 25 (IBM SPSS Inc., Chicago, Illinois, USA) szoftver segítségével végeztük.

\section{Eredmények}

A 36 férfi (55\%) és 30 nő (45\%) átlagos életkora $60,5 \pm 8,9$ év volt az adatgyüjtés időpontjában. 37 beteg (56\%) GOLD II., 27 beteg (41\%) GOLD III., míg 2 beteg (3\%) GOLD IV. stádiumba volt sorolható. A betegek klinikai adatait, legfontosabb társbetegségeit és a bevonás idején alkalmazott gyógyszeres kezelést az 1 . táblázat foglalja össze.

57 betegnél $(86,4 \%)$ megtartott $(>55 \%)$, míg 9 betegnél $(13,6 \%)$ mérsékelten csökkent bal kamrai ejekciós frak- 


\section{TÁBLÁZAT. A vizsgált COPD-s populáció klinikai adatai}

\section{COPD-s betegek $(n=66)$}

\section{Klinikai adatok}

\begin{tabular}{l|c}
\hline Kor a vizsgálat idején (év) & $60,5 \pm 8,9$ \\
\hline Férfi nem (\%) & $36(55 \%)$ \\
\hline Dohányzás (csomagév) & $33,5 \pm 26,2$ \\
\hline BSA (m²) & $1,9 \pm 0,3$ \\
\hline FEV1 (\%) & $54,6 \pm 14,8$ \\
\hline FVC (\%) & $81,2 \pm 14,8$ \\
\hline FEV1/FVC (\%) & $60,2 \pm 15,4$ \\
\hline Társbetegségek & \\
\hline Iszkémiás szívbetegség (\%) & $9(14 \%)$ \\
\hline Szisztémás hipertónia (\%) & $51(77 \%)$ \\
\hline Diabetes mellitus (\%) & $18(27 \%)$ \\
\hline Szívelégtelenség (\%) & $51(77 \%)$ \\
\hline Gyógyszerek & \\
\hline ACE-gátló (\%) & $32(48 \%)$ \\
\hline B-blokkoló (\%) & $29(44 \%)$ \\
\hline Spironolakton (\%) & $3(5 \%)$ \\
\hline Kacsdiuretikumok (\%) & $27(41 \%)$ \\
\hline (BSA: body surface area, FEV1: forced expiratory volume, FVC: forced \\
vital capacity)
\end{tabular}

ció volt észlelhető. A vizsgált betegek közül 19 (28,8\%) esetében normális bal kamrai relaxációra utaló paramétereket találtunk. 29 (43,9\%) főnél károsodott relaxációra utaló mintázat volt igazolható, míg emelkedett töltőnyomásra utaló eredmények $18(27,3 \%)$ esetben születtek. Utóbbiak közül 17 esetben $(25,8 \%)$ pszeudonormális, míg 1 betegnél (1,5\%) restriktív típusú mitrális beáramlási görbét találtunk. A bal szívfél funkcióját tükröző echokardiográfiás paramétereket és az NT-proBNP-értékeket a 2. táblázat mutatja be részletesen. A jobb szívfél funkcióját jellemző echokardiográfiás paraméterek már korábban bemutatásra kerültek (9).

Átlagosan 1653 \pm 232 nap $(4,5 \pm 0,6$ év) követési idő után vizsgáltuk meg a betegek túlélését. Ez idő alatt 5 (7,6\%) haláleset történt. Egyváltozós Cox-regressziós analízis alapján hat változó bizonyult a halálozás szignifikáns prediktorának: életkor, mitrális regurgitáció mértéke, átlagos e', átlagos S, átlagos E/e', illetve InNT-proBNP. Többváltozós Cox-regressziós analízis alapján az előbbi paraméterek közül az átlagos E/e' bizonyult a halálozás egyetlen független prediktorának (HR (95\% $\mathrm{Cl})=1,372(1,104-1,706) ; \mathrm{p}=0,004)$ (3. táblázat).

ROC-görbe segítségével megállapítottuk, hogy 9,7 az az E/e' érték, ami a lehető legmagasabb szenzitivitás-

2. TÁBLÁZAT. A teljes COPD-s populáció és a különböző prognózisú alcsoportok echokardiográfiás paraméterei

\begin{tabular}{|c|c|c|c|}
\hline $\begin{array}{c}\text { Teljes populáció } \\
\text { (n=66) }\end{array}$ & \multicolumn{2}{|c}{ Átlagos E/e' } & p-érték \\
\hline & $\mathbf{2 9 , 7}(\mathbf{n = 1 8})$ & $\mathbf{< 9 , 7}(\mathbf{n = 4 8 )}$ & \\
\hline $60,5 \pm 8,9$ & $62,5 \pm 10,1$ & $59,7 \pm 8,4$ & 0,248 \\
\hline 5 & 4 & 1 & $\mathbf{0 , 0 0 6}$ \\
\hline $59,8 \pm 5,5$ & $57,6 \pm 7,4$ & $60,7 \pm 4,5$ & 0,109 \\
\hline $11,4 \pm 1,6$ & $11,7 \pm 1,7$ & $11,3 \pm 1,6$ & 0,394 \\
\hline $11,3 \pm 1,2$ & $11,7 \pm 1,2$ & $11,1 \pm 1,2$ & 0,102 \\
\hline $106,0 \pm 25,2$ & $113,6 \pm 24,8$ & $103,2 \pm 25,0$ & 0,135 \\
\hline & & & \\
\hline $62(93,9 \%)$ & $16(88,9 \%)$ & $46(95,8 \%)$ & 0,292 \\
\hline $4(6,1 \%)$ & $2(11,1 \%)$ & $2(4,2 \%)$ & $\mathbf{0 , 0 0 3}$ \\
\hline $66,9 \pm 16,3$ & $78,9 \pm 19,4$ & $62,2 \pm 12,3$ & $\mathbf{0 , 0 0 0}$ \\
\hline $74,9 \pm 17,2$ & $86,6 \pm 14,2$ & $70,4 \pm 16,2$ & 0,632 \\
\hline $0,94 \pm 0,31$ & $0,97 \pm 0,46$ & $0,92 \pm 0,23$ & 0,094 \\
\hline $8,9 \pm 1,5$ & $8,3 \pm 1,4$ & $9,1 \pm 1,6$ & $\mathbf{0 , 0 0 0}$ \\
\hline $7,8 \pm 1,5$ & $6,6 \pm 1,3$ & $8,2 \pm 1,4$ & 0,834 \\
\hline $10,4 \pm 1,7$ & $10,3 \pm 1,9$ & $10,4 \pm 1,7$ & $\mathbf{0 , 0 0 0}$ \\
\hline $8,9 \pm 2,6$ & $12,1 \pm 2,6$ & $7,6 \pm 1,3$ & 0,214 \\
\hline $25,1 \pm 7,7$ & $27,1 \pm 9,0$ & $24,4 \pm 7,1$ & 0,741 \\
\hline $31,2 \pm 8,4$ & $31,9 \pm 5,6$ & $30,8 \pm 9,6$ & \\
\hline $19(28,8 \%)$ & $0(0 \%)$ & $19(39,6 \%)$ & \\
\hline $29(43,9 \%)$ & $7(38,9 \%)$ & $22(45,8 \%)$ & $\mathbf{0 , 0 0 0}$ \\
\hline $17(25,8 \%)$ & $10(55,55 \%)$ & $7(14,6 \%)$ & \\
\hline $1(1,5 \%)$ & $1(5,55 \%)$ & $0(0 \%)$ & \\
\hline $212 \pm 373$ & $397 \pm 655$ & $144 \pm 146$ & 0,101 \\
\hline
\end{tabular}

A szignifikáns p-értékeket bold betűtípussal jelöltük. (EF: ejekciós frakció, IVS: interventrikuláris szeptum, PWT: bal kamra hátsó falának vastagsága (posterior wall thickness), LVM: bal kamrai izomtömeg (left ventricular mass) 
3. TÁBLÁZAT. A vizsgált paraméterek hatása a túlélésre Cox-regressziós analízis alapján

\begin{tabular}{|c|c|c|c|c|}
\hline & \multicolumn{2}{|c|}{$\begin{array}{l}\text { Egyváltozós } \\
\text { Cox-regresszió }\end{array}$} & \multicolumn{2}{|c|}{$\begin{array}{l}\text { Többváltozós } \\
\text { Cox-regresszió }\end{array}$} \\
\hline & HR $(95 \% \mathrm{CI})$ & $\mathbf{p}$ & $\begin{array}{c}\text { HR } \\
(95 \% \mathrm{CI})\end{array}$ & $\mathbf{p}$ \\
\hline Életkor (év) & $\begin{array}{c}1,133 \\
(1,009-1,271)\end{array}$ & 0,035 & & \\
\hline $\operatorname{BSA}\left(m^{2}\right)$ & $\begin{array}{c}0,722 \\
(0,025-20,871)\end{array}$ & 0,849 & & \\
\hline $\begin{array}{l}\text { LVM-index } \\
\left(\mathrm{g} / \mathrm{m}^{2}\right)\end{array}$ & $\begin{array}{c}1,020 \\
(0,994-1,046)\end{array}$ & 0,129 & & \\
\hline $\begin{array}{l}V_{\max }-\text { index } \\
\left(\mathrm{ml} / \mathrm{m}^{2}\right)\end{array}$ & $\begin{array}{c}1,124 \\
(1,010-1,250)\end{array}$ & 0,032 & & \\
\hline $\begin{array}{l}\text { Mitrális regur- } \\
\text { gitáció foka }\end{array}$ & $\begin{array}{c}3,045 \\
(0,938-9,890)\end{array}$ & 0,064 & & \\
\hline $\mathrm{EF}(\%)$ & $\begin{array}{c}0,920 \\
(0,816-1,037)\end{array}$ & 0,170 & & \\
\hline$E(\mathrm{~cm} / \mathrm{s})$ & $\begin{array}{c}1,026 \\
(0,979-1,075)\end{array}$ & 0,285 & & \\
\hline $\mathrm{A}(\mathrm{cm} / \mathrm{s})$ & $\begin{array}{c}1,008 \\
(0,957-1,061)\end{array}$ & 0,770 & & \\
\hline $\begin{array}{l}\text { Átlagos S } \\
(\mathrm{cm} / \mathrm{s})\end{array}$ & $\begin{array}{c}0,505 \\
(0,225-1,133)\end{array}$ & 0,098 & & \\
\hline $\begin{array}{l}\text { Átlagos } \\
e^{\prime}(\mathrm{cm} / \mathrm{s})\end{array}$ & $\begin{array}{c}0,503 \\
(0,260-0,971)\end{array}$ & 0,041 & & \\
\hline $\begin{array}{l}\text { Átlagos a' } \\
(\mathrm{cm} / \mathrm{s})\end{array}$ & $\begin{array}{c}0,766 \\
(0,447-1,313)\end{array}$ & 0,333 & & \\
\hline Átlagos E/e' & $\begin{array}{c}1,380 \\
(1,109-1,717)\end{array}$ & 0,004 & $\begin{array}{c}1,372 \\
(1,10-1,706)\end{array}$ & 0,004 \\
\hline InNT-proBNP & $\begin{array}{c}2,248 \\
(1,036-4,875)\end{array}$ & 0,040 & & \\
\hline
\end{tabular}

A szignifikáns összefüggéseket bold betütípussal jelöltük.

sal és specificitással képes megkülönböztetni a túlélö és elhunyt COPD-s populációt (1. ábra). Az ezen cutoff érték felhasználásával készített Kaplan-Meier túl-

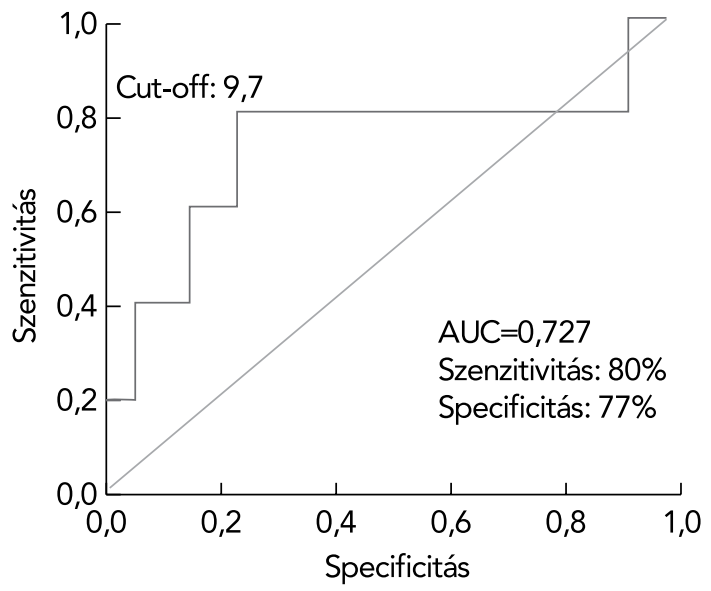

1. ÁBRA. A ROC-görbe bemutatja az $E / e^{\prime}=9,7$ cut-off érték szenzitivitását és specificitását a vizsgált populáció túlélésének vonatkozásában

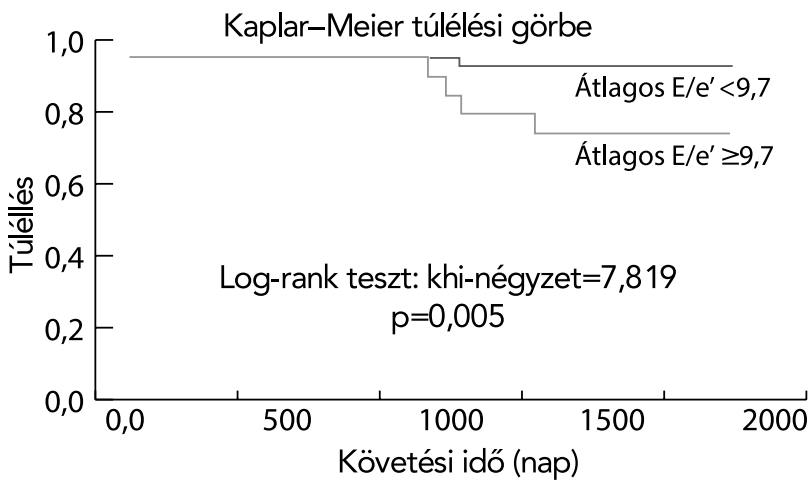

1. ÁBRA. A Kaplan-Meier túlélési görbe az E/e' érték prognosztikus szerepét demonstrálja a vizsgált populációban

élési görbét az 2. ábra, amíg a két alcsoportot jellemző vizsgálati eredményeket a 2. táblázat mutatja be. A két alcsoport szignifikánsan különbözik a bal kamrai diasztolés funkció számos paramétere tekintetében, míg az NT-proBNP-értékek különbsége nem szignifikáns.

\section{Megbeszélés}

A klasszikus „cor pulmonale” kifejezés a COPD-ben szenvedő betegekre jellemző jobbszívfél-dilatációt és -elégtelenséget takarja. Elsősorban a jobb szívfél diasztolés funkciózavara fordul elö, a csökkent cardiac outputtal járó szisztolés jobbszívfél-elégtelenség ritka (13). Többek között munkacsoportunk is igazolta korábban, hogy a jobb kamrai diasztolés funkció zavara és a töltőnyomás emelkedése jelentősen befolyásolja a COPD-s betegek funkcionális kapacitását (9).

Emellett azonban COPD-ben a balszívfél-elégtelenség is gyakori, prevalenciája $7,1 \%$ és $31,3 \%$ között változik a különböző COPD-s populációkban (14-20). A két kórkép társulása rontja a betegek életminőségét és növeli a mortalitást $(3,4)$. Jelentősen csökkent bal kamrai ejekciós frakció és a következményes HFrEF a COPD-s betegek 8-25\%-ában került leírásra $(19,21-23)$, és leggyakrabban koszorúér-betegség következménye ebben a kórképben (7). A diasztolés funkciózavar, illetve a következményes HFpEF gyakoribbnak tünik (19, 21-35). Kialakulását több mechanizmus is elösegítheti: $A$ tüdő hiperinflációja következtében szignifikánsan csökken a bal kamrai diasztolés átmérő, ami károsítja a bal kamrai relaxációt (6). A bal kamrai telődés károsodása került leírásra emelkedett pulmonalis nyomás esetén is, amit a kamrai interdependencia következményének tartanak (24). Emellett a hypoxaemia és a szisztémás gyulladás direkt is károsíthatja a bal kamrai relaxációt (2). A megnövekedett artériás stiffness etiológiai szerepe szintén ismert (5).

A diasztolés funkciózavar gyakoriságával kapcsolatos irodalmi adatok ugyanakkor ellentmondásosak, mivel a 
különböző munkacsoportok eltérő módszereket használtak a bal kamrai diasztolés funkció megítélésére.

- Boussuges és munkatársai spektrális Doppler-méréseik során a diasztolés funkciózavar jeleként csökkent E/A arányt és megnyúlt izovolumetriás relaxációs időt (IVRT) találtak COPD-s populációban, illetve kimutatták, hogy a pitvari kontrakció nagyobb szerepet játszik a bal kamrai telődésben, mint egészséges személyekben (27). A bal pitvari kontraktilis funkció ezen kompenzatorikus javulása, ami a diasztolés funkciózavar kezdeti fázisában észlelhető, nemrégiben nyert igazolást a modern strain-technika segítségével is más kórképekben (36).

- Malerba és munkatársai szintén a klasszikusan használt echokardiográfiás paraméterek (E/A arány, IVRT, decelerációs idő) segítségével a COPD-s betegek 70,9\%-ában találtak károsodott bal kamrai telödést. Különösen súlyosnak ítélték ezt a jelenséget azokban a betegekben, akiknél a tüdő statikus hiperinflációja volt jelen (32).

- Huang és munkatársai már a modern szöveti Doppler-paraméterek (e', E/e') felhasználásával a betegek $64 \%$-ában igazoltak bal kamrai diasztolés funkciózavart, míg manifeszt HFpEF 50,7\%ban volt jelen. Nem találtak különbséget a COPD különböző stádiumaiban szenvedö betegek között a diasztolés funkciózavar mértékében (37).

- López-Sánchez és munkatársai stabil állapotú, de súlyosan károsodott $\mathrm{FEV1-értékkel}(38,5 \pm 6,1 \%)$ bíró COPD-s betegek $90 \%$-ánál mutattak ki bal kamrai diasztolés funkciózavart. A betegek $80 \%$-a a károsodott relaxációjú csoportba tartozott, míg 10\%-ukban pszeudonormális mitrális beáramlási görbe volt igazolható (34).

- Hasonlóképpen, Kubota és munkatársai is a COPD-s betegek 10,5\%-ában találtak egyértelmüen emelkedett töltőnyomásra utaló E/e' értéket $(\geq 15)$ (38).

- Zhyvotovska és munkatársai a feljebb részletezett és egyéb echokardiográfiás vizsgálatok metaanalízisét végezték el. Eredményeik egyértelműen arra utalnak, hogy a bal kamrai diasztolés funkciózavar nagyobb arányban fordul elő a COPD-s betegekben, mint a hasonló korú kontrollpopulációban. A kontrollcsoportokhoz képest konzekvensen alacsonyabb $E / A$ arányt találtak a tanulmányokban. Ez azt sugallja, hogy a diasztolés funkciózavar legenyhébb formája, a „károsodott relaxáció" a leggyakoribb COPD-ben (39).

Eredményeink egybevágnak a korábbi tanulmányokéval: a bemutatott COPD-s populáció $71 \%$-ában találtunk diasztolés funkciózavart. Ez többségében károsodott relaxációt jelentett, míg emelkedett töltőnyomásra utaló eredmények a teljes populáció $27 \%$-ában születtek. Míg a COPD-s betegek bal kamrai diasztolés funkciójával kapcsolatos keresztmetszeti vizsgálat nagy szám- ban áll rendelkezésre, a követéses eredmények csekélyek: Stankovich és munkatársainak tanulmányában az E/e' arány a bármely okból bekövetkező halálozás független prediktorának bizonyult COPD-s populációban (40). Saját adataink megerősítik ezt az eredményt.

\section{Limitációk}

Vizsgálatunk legfőbb limitáló tényezője az alacsony betegszám és a követés során bekövetkezett események relatíve alacsony száma. Ennek következtében a statisztikai elemzés során alkalmazott többváltozós Cox-regressziós analízis értékelhetősége korlátozott. További limitációt jelent a vizsgálat retrospektív jellege, amely miatt a halál oka az esetek egy részében nem volt korrekten tisztázható. Így munkánkban a kardiovaszkuláris okból bekövetkező halálozást nem, csak az összhalálozást volt lehetőségünk vizsgálni.

\section{Következtetések}

Megtartott vagy mérsékelten csökkent ejekciós frakcióval bíró COPD-s populációban gyakori a bal kamrai diasztolés funkciózavar, különösen a károsodott relaxációra jellemző mintázat. A vizsgált echokardiográfiás paraméterek közül különösen nagy jelentőséggel bír az E/e' arány, amely a bármely okból bekövetkezett halálozás független prediktorának bizonyult ebben a kórképben.

\section{Nyilatkozat}

A szerzők kijelentik, hogy az eredeti közlemény megírásával kapcsolatban nem áll fenn velük szemben pénzügyi vagy egyéb lényeges összeütközés, összeférhetetlenségi ok, amely befolyásolhatja a közleményben bemutatott eredményeket, az abból levont következtetéseket vagy azok értelmezését.

\section{Irodalom}

1. Vestbo J, Hurd SS, Agusti AG, et al. Global strategy for the diagnosis, management, and prevention of chronic obstructive pulmonary disease: GOLD executive summary. Am J Respir Crit Care Med 2013; 187: 347-365. https://doi.org/10.1164/rccm.201204-0596PP 2. Hannink JD, van Helvoort HA, Dekhuijzen PN, et al. Heart failure and COPD: partners in crime? Respirology 2010; 15: 895-901. https://doi.org/10.1111/j.1440-1843.2010.01776.x

3. Hawkins NM, Virani S, Ceconi C. Heart failure and chronic obstructive pulmonary disease: the challenges facing physicians and health services. Eur Heart J 2013; 34: 2795-2803.

https://doi.org/10.1093/eurheartj/eht192

4. Díez JM, Morgan JC, García RJ. The association between COPD and heart failure risk: a review. Int J Chron Obstruct Pulmon Dis 2013; 8: 305-312. https://doi.org/10.2147/copd.s31236

5. Mills NL, Miller JJ, Anand A, et al. Increased arterial stiffness in patients with chronic obstructive pulmonary disease: a mechanism for increased cardiovascular risk. Thorax 2008; 63: 306-311. https://doi.org/10.1136/thx.2007.083493

6. Watz H, Waschki B, Meyer T, et al. Decreasing cardiac chamber sizes and associated heart dysfunction in COPD: role of hyperinflation. Chest 2010; 138: 32-38. https://doi.org/10.1378/chest.09-2810 
7. Portillo K, Abad-Capa J, Ruiz-Manzano J. Chronic obstructive pulmonary disease and left ventricle. Arch de Bronconeumol 2015; 51 227-234. https://doi.org/10.1016/j.arbr.2015.02.025

8. Rutten FH, Cramer MJ, Lammers JW, et al. Heart failure and chronic obstructive pulmonary disease: An ignored combination? Eur J Heart Fail 2006; 8: 706-711.

https://doi.org/10.1016/j.ejheart.2006.01.010

9. Faludi R, Hajdu M, Vértes V, et al. Diastolic dysfunction is a contributing factor to exercise intolerance in COPD. COPD 2016; 13 : 345-351. https://doi.org/10.3109/15412555.2015.1084614

10. Lang RM, Bierig M, Devereux RB, et al. Recommendations for chamber quantification. J Am Soc Echocardiogr 2005; 18: 1440-1463. https://doi.org/10.1016/j.echo.2005.10.005

11. Rudski LG, Lai WW, Afilalo J, et al. Guidelines for the echocardiographic assessment of the right heart in adults. J Am Soc Echocardiogr 2010; 23: 685-713. https://doi.org/10.1016/j.echo.2010.05.010 12. Nagueh SF, Smiseth OA, Appleton CP, et al. Recommendations for the evaluation of left ventricular diastolic function by echocardiography. J Am Soc Echocardiogr 2016; 29: 277-314.

https://doi.org/10.1016/j.echo.2008.11.023

13. Hoeper MM, Barbera JA, Channick RN, et al. Diagnosis, assessment, and treatment of non-pulmonary arterial hypertension pulmonary hypertension. J Am Coll Cardiol 2009; 54: 85-96.

https://doi.org/10.1016/j.jacc.2009.04.008

14. Finkelstein J, Cha E, Scharf SM. Chronic obstructive pulmonary disease as an independent risk factor for cardiovascular morbidity. Int J Chron Obstruct Pulmon Dis 2009; 4: 337-49.

https://doi.org/10.2147/COPD.S6400

15. Müllerova H, Agusti A, Erqou S, et al. Cardiovascular comorbidity in COPD: systematic literature review. Chest 2013; 144: 1163-78. https://doi.org/10.1378/chest.12-2847

16. Sidney S, Sorel M, Quesenberry CP, et al. COPD and incident cardiovascular disease hospitalizations and mortality: Kaiser Permanente Medical Care Program. Chest 2005; 128: 2068-75.

https://doi.org/10.1378/chest.128.4.2068

17. Mapel DW, Dedrick D, Davis K. Trends and cardiovascular comorbidities of COPD patients in the Veterans Administration Medical System, 1991-1999. COPD 2005; 2: 35-41. https://doi.org/10.1081/ COPD-200050671

18. Curkendall SM, DeLuise C, Jones JK, et al. Cardiovascular disease in patients with chronic obstructive pulmonary disease, Saskatchewan Canada cardiovascular disease in COPD patients. Ann Epidemiol 2006; 16: 63-70.

https://doi.org/10.1016/j.annepidem.2005.04.008

19. Flu WJ, van Gestel YR, van Kuijk JP, et al. Coexistence of COPD and left ventricular dysfunction in vascular surgery patients. Respir Med 2010; 104: 690-6. https://doi.org/10.1016/j.rmed.2009.11.013

20. Agusti A, Calverley PMA, Celli B, et al. Characterisation of COPD heterogeneity in the ECLIPSE cohort. Respir Res 2010; 11: 122. https://doi.org/10.1186/1465-9921-11-122

21. Gupta NK, Agrawal RK, Srivastav AB, et al. Echocardiographic evaluation of heart in chronic obstructive pulmonary disease patient and its co-relation with the severity of disease. Lung India 2011; 28 : 105-9. https://doi.org/10.4103/0970-2113.80321

22. Macchia A, Rodriguez Moncalvo JJ, Kleinert M, et al. Unrecognized ventricular dysfunction in COPD. Eur Respir J 2012; 39: 51-8. https://doi.org/10.1183/09031936.00044411

23. Freixa X, Portillo K, Paré $C$, et al. Echocardiographic abnormalities in patients with COPD at their first hospital admission. Eur Respir J 2013; 41: 784-91. https://doi.org/10.1183/09031936.00222511

24. Funk GC, Lang I, Schenk $P$, et al. Left ventricular diastolic dysfunction in patients with COPD in the presence and absence of el- evated pulmonary arterial pressure. Chest 2008; 133: 1354-1359. https://doi.org/10.1378/chest.07-2685

25. Schena M, Clini E, Errera D, et al. Echo-Doppler evaluation of left ventricular impairment in chronic cor pulmonale. Chest 1996; 109: 1446-51. https://doi.org/10.1378/chest.109.6.1446

26. Tutar E, Kaya A, Gulec S, et al. Echocardiographic evaluation of left ventricular diastolic function in chronic cor pulmonale. Am J Cardiol 1999; 83: 1414-7.

https://doi.org/10.1016/S0002-9149(99)00111-3

27. Boussuges A, Pinet $C$, Molenat $F$, et al. Left atrial and ventricular filling in chronic obstructive pulmonary disease. An echocardiographic and Doppler study. Am J Respir Crit Care Med 2000; 162: 670-5. https://doi.org/10.1164/ajrccm.162.2.9908056

28. Ozer N, Tokgozulu L, Coplu L, et al. Echocardiographic evaluation of left and right ventricular diastolic function in patients with chronic obstructive pulmonary disease. J Am Soc Echocardiogr 2001; 14: 557-61. https://doi.org/10.1067/mje.2001.111474

29. Yilmaz R, Gencer M, Ceylan E, et al. Impact of chronic obstructive pulmonary disease with pulmonary hypertension on both left ventricular systolic and diastolic performance. J Am Soc Echocardiogr 2005; 18: 873-81. https://doi.org/10.1016/j.echo.2005.01.016 30. Acikel M, Kose N, Aribas A, et al. The effect of pulmonary hypertension on left ventricular diastolic function in chronic obstructive lung disease: a tissue Doppler imaging and right cardiac catheterization study. Clin Cardiol 2010; 33: E13-8.

https://doi.org/10.1002/clc.20568

31. Sabit R, Bolton CE, Fraser AG, et al. Subclinical left and right ventricular dysfunction in patients with COPD. Respir Med 2010; 104: 1171-8. https://doi.org/10.1016/j.rmed.2010.01.020

32. Malerba M, Ragnoli B, Salameh M, et al. Subclinical left ventricular diastolic dysfunction in early stage of chronic obstructive pulmonary disease. J Biol Regul Homeost Agents 2011; 25: 443-451.

33. Bhattacharyya $P$, Acharjee $D$, Ray $S N$, et al. Left ventricular diastolic dysfunction in COPD may manifest myocardial ischemia. COPD 2012; 9: 305-309. https://doi.org/10.3109/15412555.2012.661805

34. López-Sánchez M, Muñoz-Esquerre M, Huertas D, et al. High prevalence of left ventricle diastolic dysfunction in severe COPD associated with a low exercise capacity: a cross-sectional study. PLoS One 2013; 8: e68034. https://doi.org/10.1371/journal.pone.0068034 35. Schoos MM, Dalsgaard M, Kjærgaard J, et al. Echocardiographic predictors of exercise capacity and mortality in chronic obstructive pulmonary disease. BMC Cardiovasc Disord 2013; 13: 84.

https://doi.org/10.1186/1471-2261-13-84

36. Porpáczy A, Nógrádi $A$, Kehl D, et al. Impairment of left atrial mechanics is an early sign of myocardial involvement in systemic sclerosis. J Card Fail 2018; 4: 234-242.

https://doi.org/10.1016/j.cardfail.2018.02.012

37. Huang YS, Feng YC, Zhang J, et al. Impact of chronic obstructive pulmonary diseases on left ventricular diastolic function in hospitalized elderly patients. Clin Interv Aging 2014; 10: 81-87.

https://doi.org/10.2147/CIA.S71878

38. Kubota Y, Asai K, Murai K, et al. COPD advances in left ventricular diastolic dysfunction. Int J Chron Obstruct Pulmon Dis 2016; 11: 649-655. https://doi.org/10.2147/COPD.S101082

39. Zhyvotovska A, Yusupov D, Kamran H, et al. Diastolic dysfunction in patients with chronic obstructive pulmonary disease: a metaanalysis of case controlled studies. Int J Clin Res Trials 2019; 4: 137-148. https://doi.org/10.15344/2456-8007/2019/137

40. Stankovic I, Marcun R, Janicijevic A, et al. Echocardiographic predictors of outcome in patients with chronic obstructive pulmonary disease. J Clin Ultrasound 2016; 45: 211-221.

https://doi.org/10.1002/jcu.22433 